\title{
EVALUATION OF THE ACCURACY OF "OTTAWA ANKLE RULES" FOR PREDICTING FRACTURES IN ACUTE ANKLE AND MIDFOOT INJURIES
}

\author{
Dwivedi $\mathbf{R}^{1}$, Ale SB ${ }^{1}$
}

\section{ABSTRACT}

INTRODUCTION: Twisting injuries of ankle and foot are one of the most common injuries seen in emergency department and are the most common sports injuries. Almost all such cases are investigated by X-rays to rule out fractures, but clinically significant fractures are detected only in a small number of cases (approximately 15\%). Ottawa Ankle Rules (OARs) are screening tools, applied in acute ankle and foot injuries to exclude those cases that are not likely to have fractures and thereby reduce the number of unnecessary X-rays. At the same time, all clinically significant fractures are included and not a single clinically significant fracture is missed when OARs are applied properly. This study was conducted to evaluate the accuracy of "Ottawa Ankle Rules" in our setup.

METHODS:This prospective study was conducted in the Emergency and Orthopaedics Department of Lumbini Medical College Teaching Hospital, Palpa. Eighty patients were included in this study. Fifty one patients were in ankle group and 30 patients were in midfoot group. All patients were sent for X-rays after evaluating them according to OARs.

RESULTS: Among 81 cases, 13 clinically significant fractures were detected. Sensitivity of the OARs for detecting fractures was $100 \%$. Specificity of the OARs for detecting fractures was $36.76 \%$ for combined ankle and midfoot zones, $36.36 \%$ for the ankle zone, and $37.5 \%$ for the midfoot zone. Negative predictive value was calculated as $1(100 \%)$. Potential of OARs to reduce unnecessary radiographs was calculated $30.86 \%$.

CONCLUSION: OARs are very accurate and highly sensitive tools for detecting fractures in acute ankle and midfoot injuries. Implementation of these rules would lead to significant reduction in the number of radiographs and thereby reduce the cost of the treatment, radiation exposure and waiting time of patients at hospital.

KEYWORDS: Ankle sprain, Foot, Ottawa ankle rules

1. Lecturer, Department of Orthopaedics, Lumbini Medical College and Teaching Hospital, Palpa, Nepal

\author{
For Correspondence \\ Dr. Rajeev Dwivedi \\ Lecturer, \\ Department of Orthopaedics, \\ Lumbini Medical College and Teaching Hospital, Palpa, Nepal \\ Email:rd172002@gmail.com
}




\section{INTRODUCTION}

Acute ankle and foot injuries are among the most common injuries seen in Emergency Departments(ED) and are the most common sports related injuries. ${ }^{1,2}$ Almost all patients with such injuries undergo X-ray evaluation, whereas less than $15 \%$ have clinically significant fractures. ${ }^{3-5}$ This figure shows that significant number of patients are subjected to unnecessary X- ray exposure. So, there was a need for clinical tests that can reduce the unnecessary X-rays ordered for such injuries, while at the same time, these tests should have ability to include all clinically significant fractures and no fracture should be missed. Steill et al ${ }^{6,7}$ developed and validated such tests and named then Ottawa ankle rules (OARs). These rules are based on pain, bony tenderness and weight bearing ability (Fig. 1).

Figure 1: The Ottawa Ankle Rules for ankle and foot radiography $^{7}$
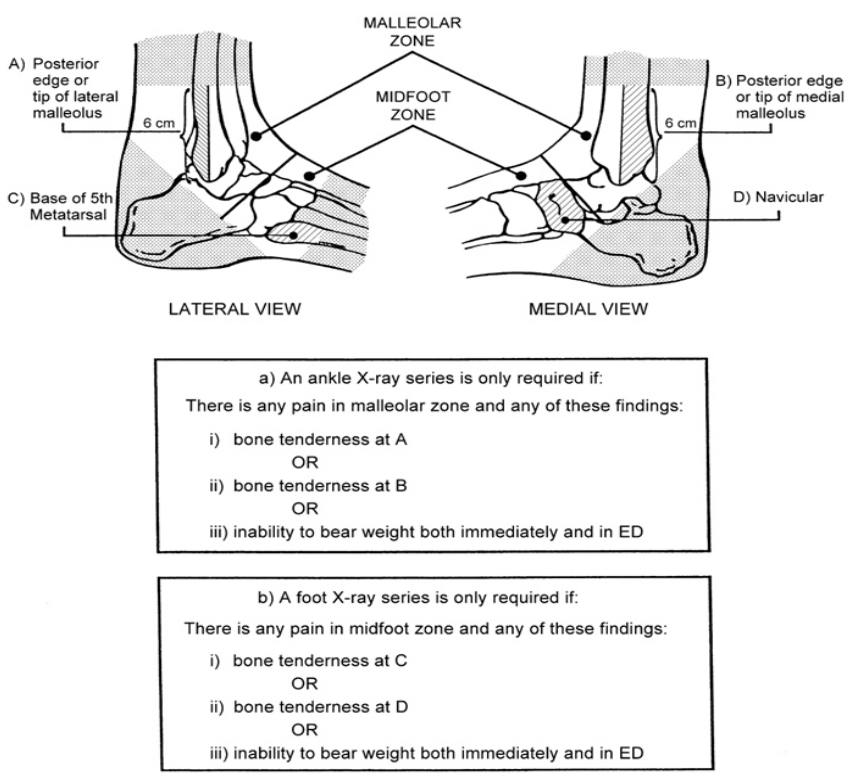

According to OARs, X-rays of the ankle is done, if there is pain in the malleolar zone and either $(a)$ inability to bear weight immediately and in the ED (four steps) and/or (b) bone tenderness at the posterior edge or tip of either malleolus. They recommend midfoot X-ray only if there is pain in the midfoot zone and either $(a)$ inability to bear weight immediately and in the emergency department (four steps) and/or $(b)$ bone tenderness at the navicular or the base of fifth metatarsal.

OARs have been studied and validated in several countries. ${ }^{8-13}$ In the systemic review done by Bachman et $\mathrm{al}^{14}$ the sensitivity of the OARs ranges from $96.4 \%$ to $99.6 \%$ and specificity ranges from $47.9 \%$ to $26.3 \%$. However, in some studies OARs couldn't be validated. ${ }^{15,16}$ Since ankle and foot injuries are also common in our hospital and all cases are sent for X-rays, we evaluated the accuracy of the OARs in our set-up.

\section{MATERIALS AND METHODS}

This prospective study was conducted at Lumbini Medical College Teaching Hospital, Palpa in the Department of Emergency and Outpatient Department of Orthopaedics from December 2010 to July 2011, over a period of 8 months. This study was approved by ethical committee and a written informed consent was obtained from each patient for inclusion in the study. All adult patients coming to this institute with complaints of ankle and midfoot pain secondary to closed acute ankle and midfoot injuries were included in this study. Exclusion criteria were patients less than 18 years of age, patients with isolated injuries of skin, patients referred from outside hospital with radiography, injuries more than 10 days old, unconscious patients, patients with previously symptomatic ankle, intoxicated patients, insensate leg, open fractures, evidence of neurovascular compromise and patients with obvious ankle and foot deformities.

Cases were evaluated according to OARs (fig.1).Malleolar and midfoot zones were defined as described by Stiell et al. ${ }^{6,7}$ Tenderness was evaluated first followed by assessment of weight bearing abilities. Weight bearing was described as the ability to transfer weight twice onto each leg (a total of four steps) regardless of limping or discomfort. Clinical diagnosis was reached and recorded. X-rays were sent for both OAR negative and positive cases. X-rays ordered for ankle was Antero-Posterior (AP), Lateral (Lat.)and mortise view. For foot, AP, Lateral and oblique views were ordered. The X-rays were evaluated and fracture fragment displacement more than $3 \mathrm{~mm}$ breadth was considered as clinically significant fracture. OARs were evaluated by calculating sensitivity, specificity and predictive values. Amount of X-rays that can be reduced when OARs are applied was calculated.

\section{RESULTS}

We studied a total of 81 patients (51 in ankle group and 30 in midfoot group). All patients underwent $\mathrm{x}$-ray evaluation, giving $100 \%$ radiography rate. Twisting injury was the commonest mechanism of injury in both ankle and midfoot group. Among 51 patients in ankle group, 35(68.62\%) were diagnosed as OARs positive. Out of 35 OAR positive cases, 7 patients had clinically significant fracture. Among 30 patients in midfoot group, $21(70 \%)$ patients were diagnosed as OARs positive. Out of 21 patients 6 had clinically 
significant fractures. None of the patients in OAR negative group had clinically significant fracture. Patient's characteristics, pattern of fractures, outcome and performance of Ottawa ankle rules are shown in detail in table 1, 2, 3 and 4 respectively.

\section{Table 1: Patient characteristics}

\begin{tabular}{|c|c|c|}
\hline Patient characteristics & Ankle group & Foot group \\
\hline Total no. of cases $(81)$ & 51 & 30 \\
\hline Age (mean) & 35.78yrs(st.dev.11.39) & 36.4 (st.dev.11.19) \\
\hline Sex( male/female) & $28 / 23(54.9 \% / 45.1 \%)$ & $18 / 12(60 \% / 40 \%)$ \\
\hline Time since injury & $\begin{array}{l}\text { Mean : } 20.05 \mathrm{hrs} \\
\text { Range: } 1 \mathrm{hrs} \text { to } 140 \mathrm{hrs}\end{array}$ & $\begin{array}{l}\text { Mean }: 25.2 \mathrm{hrs} \\
\text { Range }: 1 \mathrm{hrs} \text { to } 168 \mathrm{hrs}\end{array}$ \\
\hline Side affected (R/L) & $30 / 21$ & $18 / 12$ \\
\hline Mechanism of injury & $\begin{array}{l}\text { Twisting } 43 \\
\text { Fall from height } 4 \\
\text { RTA } 4 \\
\text { Direct trauma } 0\end{array}$ & 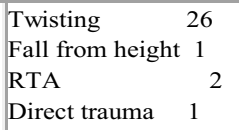 \\
\hline Swelling & $\begin{array}{l}\text { Mild :34 cases } \\
\text { Moderate: } 17 \text { cases } \\
\text { Severe: } 0 \text { case }\end{array}$ & $\begin{array}{l}\text { Mild }: 17 \text { cases } \\
\text { Moderate }: 13 \text { cases } \\
\text { Severe: } 0 \text { case }\end{array}$ \\
\hline Ecchymosis present in & 6 cases $(11.76 \%)$ & $2(6.6 \%)$ case \\
\hline OARs positive cases & 35 & 21 \\
\hline $\begin{array}{l}\text { Clinically Significant } \\
\text { fractures }\end{array}$ & $7(13.7 \%)$ cases & $6(20 \%)$ cases \\
\hline
\end{tabular}

Table 2: Fracture pattern

\begin{tabular}{|l|c|}
\hline Total no of fractures & $\mathbf{1 3 ~ ( 1 6 . 0 4 \% )}$ \\
\hline Lateral malleolus fracture & 6 \\
\hline Medial malleolus fracture & 1 \\
\hline Base of $5^{\text {th }}$ metatarsal fracture & 5 \\
\hline Navicular fracture & 1 \\
\hline
\end{tabular}

Table 3: Outcome of OARs for ankle, midfoot and combined ankle and midfoot groups

\begin{tabular}{|l|c|c|c|c|c|c|c|c|c|}
\hline & \multicolumn{2}{|l|}{ Ankle zone } & \multicolumn{3}{l|}{ Midfoot zone } & \multicolumn{2}{l|}{$\begin{array}{l}\text { Combined } \\
\text { ankle and } \\
\text { midfoot zone }\end{array}$} \\
\hline & OAR+ & OAR- & Total & OAR + & OAR- & Total & OAR + & OAR- & Total \\
\hline Fracture & 7 & 0 & 7 & 6 & 0 & 6 & 13 & 0 & 13 \\
\hline $\begin{array}{l}\text { No } \\
\text { fracture }\end{array}$ & 28 & 16 & 44 & 15 & 9 & 24 & 43 & 25 & 68 \\
\hline Total & 35 & 16 & 51 & 21 & 9 & 30 & 56 & 25 & 81 \\
\hline
\end{tabular}

\section{Table 4: Performance of OARs}

\begin{tabular}{|l|l|l|l|l|l|}
\hline & Sensitivity & Specificity & $\begin{array}{l}\text { Positive } \\
\text { predictive } \\
\text { value }\end{array}$ & $\begin{array}{l}\text { Negative } \\
\text { predictive } \\
\text { value }\end{array}$ & $\begin{array}{l}\text { X-ray } \\
\text { that could } \\
\text { be saved }\end{array}$ \\
\hline Ankle zone & $1(100 \%)$ & $36.36 \%$ & $20 \%$ & $1(100 \%)$ & $31.37 \%$ \\
\hline Midfoot zone & $1(100 \%)$ & $37.5 \%$ & $28.57 \%$ & $1(100 \%)$ & $30 \%$ \\
\hline $\begin{array}{l}\text { Combined } \\
\text { ankle and } \\
\text { midfoot zone }\end{array}$ & $1(100 \%)$ & $36.76 \%$ & $23.21 \%$ & $1(100 \%)$ & $30.86 \%$ \\
\hline
\end{tabular}

\section{DISCUSSION}

Several studies have been performed since 1981 to develop clinical rules for evaluation of acute ankle and midfoot injuries regarding need of X-rays in such injuries. ${ }^{5-7,17-21}$ OARs were developed and validated by its Canadian inventors ${ }^{6,7}$ and used in various clinical settings. OARs are easy to memorize and simple to apply, in addition, these rules have been successfully and favorably validated in various countries. ${ }^{6-13}$ However, without evaluation, even well-defined decision making rules are not suitable for application in all clinical settings due to differences in patients' characteristics, different clinical settings and behavior of treating physicians'. Moreover, some study results have rejected the generalization of the OARs. ${ }^{15,16}$ Therefore, evaluation of the OARs was considered in this study.

In present study, twisting injury was the most common mechanism of injury. This result was similar to several other studies worldwide. ${ }^{6-13}$ Result of present study is similar to those of Stiell et $\mathrm{al}^{6,7}$ and various other studies. ${ }^{8-13}$ In this study, sensitivity of OAR was calculated $100 \%$. That means all patients with clinically significant fracture were picked up by OARs and none of the clinically significant fractures were missed. Specificity was calculated $36.6 \%$ for ankle group, $37.5 \%$ for midfoot group and $36.76 \%$ for combined ankle and midfoot group. Specificity of OARs appears to be moderate and about two third of cases were diagnosed as false positive. Negative predictive value (NPV) was calculated $100 \%$ for ankle, midfoot and for combined ankle and midfoot group. That means chances of getting clinically significant fractures in those patients who were diagnosed as OAR negative was zero. With application of OARs, the amount of X-rays that could be saved was calculated as $30.86 \%$. This figure shows that approximately one third of the X-rays could be avoided with application of OARs. Though X-ray is a low cost investigation, it is done in high volume and is not free of hazards. Therefore, reduction in X-rays even by one third can lead to significant impact on our heath care cost along with reduction in radiation hazards.

\section{CONCLUSION}

OARs are highly sensitive tools, which can be used for screening of patients with acute ankle and midfoot injuries regarding need for radiological evaluation. Application of OARs can reduce significant number of X-rays thereby reducing the cost of treatment and radiation exposure as well as saving the time of patients and hospital staffs. This study was conducted in single centre with relatively small sample size. Therefore, further studies are required with large 
samples, in hospitals of different levels including community health centers and by doctors of different levels of clinical skill and expertise.

\section{REFERENCES}

1. Boruta PM, Bishop JO, Braly WG, Tullos HS. Acute lateral ankle ligament injuries: a literature review. Foot Ankle 1990; 11:10713. http://dx.doi.org/10.1177/107110079001100210 PMid: 2125020

2. Balduini FC, Vegso JJ, Torg JS, Torg E. Management and rehabilitation of ligamentous injuries to the ankle. Sports Med 1987;4:36480. http://dx.doi.org/10.2165/00007256198704050-00004

3. Montaque AP, Mc Quillan RF. Clinical assessment of apparently sprained ankle and detection of fracture. Injury 1985; 16:5456. http://dx.doi.org/10.1016/0020-1383(85) 90082-8

4. Stiell IG, McDowell I, Nair RC, Aeta H, Greenberg G, McKnight RD et al. Use of radiography in acute ankle injuries: physicians' attitudes and practice. Can Med Assoc J 1992; 147:16718.

5. Sujitkumar P, Hadfield JM, Yates TW. Sprain or fracture? An analysis of 2000 ankle injuries. Arch Emerg Med 1986; 3:1016. http://dx.doi.org/10.1136/emj.3.2.101 PMid:3089238 PMCid:PMC1285323

6. Stiell IG, Greenberg GH, McKnight RD, Nair RC, McDowell I, Worthington JR. A study to develop clinical decision rules for the use of radiography in acute ankle injuries. Ann Emerg Med 1992;21:3849.http://dx.doi.org/10.1016/S0196-0644(05) 82656-3

7. Stiell IG, Greenberg GH, McKnight RD, Nair RC, McDowell I, Reardon $M$ et al. Decision rules for the use of radiography in acute ankle injuries: refinement and prospective validation. JAMA 1993; 269:112732.http://dx.doi.org/10.1001/ jama. 1993.03500090063034http://dx.doi.org/10.1001/jama.269.9. 1127 PMid:8433468

8. Auleley GR, Kerboull L, Durieux P, Cosquer M, Courpied JP, Ravaud P. Validation of Ottawa ankle rules in France: a study in surgical emergency department of teaching hospital .Ann Emeg Med .1998;32: 14-18. http://dx.doi.org/10.1016/S01960644(98)70093-9

9. Szczesny G, Sypniewski M, Deszczynski J. Applicatoin of the Ottawa ankle rules in the ankle and midfoot injuries: verification of the method on the basis of own material. Chirurgia Narzadow Ruchu I Ortopedia Polska. 1999; 64:433439. PMid: 10575796

10. Yduen MC. SIm SW, Lam HS, Tung WK. Validation of the Ottawa ankle rules in a Hong Kong ED. Am.J. Emerg. Med.
2001; 19:429-432.http://dx.doi.org/10.1053/ajem.2001.24474 PMid:11555805

11. Wynn-Thomas S, Love T, McLeod D, Vernall S, Kljakovic M. Dowell A et al. The Ottawa ankle rules for the use of the diagnostic $x$-ray in the after hours medical centre in New Zealand. New Zealand Med.J. 2002; 115:184.

12. Shahram Yazdani, Hesam Jahandideh, Hossein Ghofrani.Validation of the Ottawa Ankle Rules in Iran: A prospective survey. BMC Emergency Medicine 2006, 6:3 http://dx.doi.org/10.1186/1471-227X-6-3 PMid:16480520 PMCid:PMC1386702

13. M. Marinelli, A.Di Giullio, M. Macini. Validation of the Ottawa ankle rules in a second-level trauma center in Italy. JOrthopaed Traumatol 2007, 8:1620. http://dx.doi.org/10.1007/s10195-007-0156-y

14. Bachmann LM, Kolb E, Koller MT, Steurer J, Riet GL. Accuracy of Ottawa ankle rules to exclude fractures of the ankle and midfoot: systematic review. BMJ 2003, 326:417.http://dx.doi.org/1 0.1136/bmj.326.7386.417 PMid:12595378 PMCid: PMC 149439

15. Kelly AM, Richards D, Kerr L, Grant J, O'Donovan P, Basire K et al. Failed validation of a clinical decision rule for the use of radiography in acute ankle injury. NZ med J. 1994; 107:2945.PMid:8093158

16. Tay SY, Thoo FL, Sitoh YY, Seow E, Wong HP. The Ottawa Ankle Rules in Asia: validating a clinical decision rule for requesting $x$-rays in twisting ankle and foot injuries. J. Emerg. Med. 1999;17: 945-94. http://dx.doi.org/10.1016/S0736-4679(99) 00120-1

17. Brooks SC, Potter BT, Rainey JB. Inversion injuries of the ankle: clinical assessment and radiographic review. BMJ 1981; 282:6078. http://dx.doi.org/10.1136/bmj.282.6264.607 PMid:6781589 PMCid:PMC1504464

18. Vargish T, Clarke WR. The ankle injury: indications for the selective use of $x$-rays. Injury 1983; 14:50712. http://dx.doi.org /10.1016/0020-1383(83)90053-0

19. Gleadhill DNS, Thomson JY, Simms P. Can more efficient use be made of $x$-ray examinations in the accident and emergency department? BMJ 1987; 294:9437.http://dx.doi.or g/10.1136 /bmj. 294.6577.943 PMid:3107669 PMCid:PMC1246007

20. Brand DA, Frazier WH, Kohlhepp WC, Shea KM, Hoefer AM, Ecker MD et al. A protocol for selecting patients with injured extremities who need x-rays. N Engl J Med 1982; 306:3339. http://dx.doi.org/10.1056/NEJM198202113060604 PMid: 7054709

21. Svenson J. Need for radiographs in acutely injured ankle. Lancet 1988;1:2445.http://dx.doi.org/10.1016/S0140-6736 (88) $91098-7$ 